\title{
Adoption of Energy-Efficient Home Appliances: Extending the Theory of Planned Behavior
}

\author{
Muhammad Yaseen Bhutto ${ }^{1}$, Xiaohui Liu ${ }^{2, *}$, Yasir Ali Soomro ${ }^{3}{ }^{\circ}$, Myriam Ertz $^{4} \oplus$ and Yasser Baeshen ${ }^{3}$ \\ 1 Economics and Management School, Wuhan University, Wuhan 430072, China; yaseen_bhutto@whu.edu.cn \\ 2 School of Information Management, Wuhan University, Wuhan 430072, China \\ 3 Faculty of Economics and Administration, King Abdulaziz University, Jeddah 21577, Saudi Arabia; \\ dr.yasir@hotmail.com (Y.A.S.); ybaeshen@kau.edu.sa (Y.B.) \\ 4 Labo NFC, Department of Economics and Administrative Sciences, University of Quebec in Chicoutimi, \\ Saguenay, QC G7H 2B1, Canada; Myriam_Ertz@uqac.ca \\ * Correspondence: xiaohuiliu@whu.edu.cn
}

Citation: Bhutto, M.Y.; Liu, X.; Soomro, Y.A.; Ertz, M.; Baeshen, Y. Adoption of Energy-Efficient Home Appliances: Extending the Theory of Planned Behavior. Sustainability 2021, 13, 250. https://doi.org/10.3390/ su13010250

Received: 3 December 2020 Accepted: 24 December 2020 Published: 29 December 2020

Publisher's Note: MDPI stays neutral with regard to jurisdictional clai$\mathrm{ms}$ in published maps and institutional affiliations.

Copyright: (C) 2020 by the authors. Licensee MDPI, Basel, Switzerland. This article is an open access article distributed under the terms and conditions of the Creative Commons Attribution (CC BY) license (https:// creativecommons.org/licenses/by/ $4.0 /)$.

\begin{abstract}
This research applies an extended theory of planned behavior (TPB) to empirically investigate consumers' intentions in Pakistan to purchase energy-efficient appliances (EEAs). Most developing countries face energy crises. As a result, many countries consider EEAs to be part of the solution to energy-related problems and teach sustainable consumption behavior to consumers. Previous studies have neglected developing countries in this context, yet developing markets have great potential for EEA adoption. To understand EEA adoption, we incorporated such variables as warm glow benefits, utilitarian environmental benefits, normative beliefs, and moral obligations as antecedents to TPB variables. The moderating effect of eco-literacy between attitude, subjective norms, perceived behavioral control (PBC), and purchase intention toward EEAs are also examined. Data was gathered through a survey questionnaire from 673 Pakistani consumers to empirically test the proposed hypotheses. The results reveal that utilitarian environmental benefits and warm glow benefits significantly influence attitudes toward EEAs. The findings also show a positive effect of normative beliefs on subjective norms. The interaction effect of eco-literacy positively influences the relationship between attitude and purchase intention, with similar results for subjective norms and purchase intention. However, no significant moderating effect of eco-literacy is found between PBC and purchase intention. Furthermore, we performed multi-group analysis to explore significant group differences by utilizing socio-demographic variables such as gender, age, education, and income. The results show significant group differences, with females' purchasing behavior, younger consumers, and educated consumers being more readily influenced. Finally, insights for policymakers, suggestions and future directions are discussed.
\end{abstract}

Keywords: energy-efficient appliances; utilitarian environmental benefits; warm glow benefits; normative beliefs; moral obligations; theory of planned behavior; eco-literacy; purchase intention

\section{Introduction}

As environmental sustainability becomes increasingly important [1-3], rise in energy consumption has caused concerns worldwide and could impede the achievement of the United Nations' sustainable development goals for 2030. In an attempt to address these issues, policies emphasizing energy efficiency have grown in prominence over the recent decades. For example, the European Commission devised a plan to reduce energy consumption by $27 \%$ [4]. Greater energy efficiency is considered to be a significant way of achieving the global objective of reduced energy use and addressing climate change and could be achieved through improved and quicker dissemination of energy-efficient units. Increased energy efficiency may help to reduce fossil fuel consumption and $\mathrm{CO}_{2}$ emissions [5]. According to Ek and Söderholm [6], policymakers believe that consumers should be made more aware of the environmental side effects of their energy consumption 
and that environmentally beneficial household-related activities such as recycling and buying eco-labeled products, should be enforced, so as to change consumer behavior and reduce electricity consumption.Urban and Ščasný [7] argued that consumers who use energy-efficient appliances (EEAs) could reduce their energy consumption and its harmful environmental impacts. According to Waris and Hameed [8], environmental policymakers increasingly emphasize the responsibility of the individual consumer for the environmental side effects of their acts, and many environmental goals are expressed in terms of household-related activities. These include, for instance, recycling, purchasing of green-labeled products, and activities that decrease electricity use. Increased energy efficiency can generally help reduce fossil fuel consumption and $\mathrm{CO}_{2}$ emissions [5]. In a study of energy efficiency and appliance purchase, Tan et al. [2] pointed out that in order to decrease energy consumption, an increase in energy use efficiency (through the use of higher-efficiency appliances) and the encouragement of more environmental consumer behaviors (through better use of electrical appliances) should be promoted. Similarly, Oikonomouet al. [9] stated that investing in energy-efficient appliances (EEAs) is likely to save more energy than energy curtailment. Given the long lifecycle of appliances, buying energy-efficient products is better for both the economy and the environment $[9,10]$. A recent study found that home appliances account for $70 \%$ of China's carbon dioxide emissions and that air conditioners, refrigerators, and televisions are responsible for $50 \%$ of these emissions [11]. Minimizing energy consumption and greenhouse gas emissions through EEAs appears, therefore, to be a desirable strategy.

Intensive research into energy-efficient behavior has been conducted in developed economies such as the United Kingdom, Australia, the Netherlands, Switzerland, the United States, and Germany [6,12-15] and in emerging economies including China, Malaysia, South Korea, Vietnam, and India [2,16-19]. However, research into intentions to purchase EEAs in developing countries would appear to be crucial since, in those countries, electricity demand is estimated to increase by $30 \%$ by 2040 [20]. Pakistan is one such developing economy. The country is the world's sixth largest, with a population of 208 million, and it has been hit by a severe energy crisis that deeply impacted economic growth and created political instability [21]. A lack of energy is estimated to cost the country $4 \%$ of its GDP. Moreover, the future energy demand for industrial purposes is expected to rise at an annual rate of $3.8 \%$, while energy demand for domestic use is expected to increase at the staggeringly high annual rate of 9\% [22]. High levels of expenditure on electronic and electrical products for domestic, industrial, and commercial purposes have increased energy consumption [23]. Moreover, during the last 15 years, $85 \%$ of new household consumers have been added, and by 2050, a threefold increase is expected [22]. An Energy Standard and Labeling System Scheme, adopted by the Ministry of Energy, has been introduced in Pakistan since 2014. Under this scheme, all household appliances such as cooling fans, washing dryers, and air conditioners must have energy-efficient labels [24]. This legislation encouraged appliance manufacturers to compete on energy efficiency criteria. However, past research has shown that Pakistani consumers have a low propensity to purchase EEAs and that, for the most part, the country is still in the early stages of its ecological transition $[25,26]$. Similarly, Waris and Hameed [8] call for additional research efforts to examine the progress of consumers' attitudes, intentions, and behaviors toward EEA consumption in developing countries.

In order to understand how to encourage consumers to purchase EEAs, the majority of research into energy-saving behaviors has focused on the roles of attitude, beliefs, and norms in shaping consumer purchase behavior $[19,25,27,28]$. Moreover, rooted in the theory of planned behavior (TPB), the literature largely addresses consumer purchase intentions toward EEAs; researchers have included several variables in the TPB including norms [29], price [11,30,31], environmental knowledge and concern [32,33], and the use of innovative technology to reduce carbon footprints [34], while previous energy studies have paid attention to consumer values [25]. However, the influence and role of (green) psychological benefits remain under-theorized, even though perceived benefits play a key role in 
consumer decision-making processes [35-37]. Past research has identified two distinctive types of benefit that may affect purchase intentions; namely utilitarian environmental benefits, and "warm glow" benefits [18,38]. Psychological benefits such as these can be critical determinants of environmentally friendly purchasing $[37,38]$. People are willing to pay more for green products if they can experience the psychological benefit of a warm glow and the positive emotional state consequent from saving resources, benefiting other people and the Earth's environment $[39,40]$. Past studies have found that such positive emotions directly or indirectly influence consumer attitudes [1,38]. Tangential research has suggested that normative beliefs and moral obligations play a considerable role in forming consumers' ecological intentions [41]. Moral issues have been found to influence the subjective norms that determine behavior in moral situations [42]. Moreover, Icek and Ajzen [43] highlighted the significance of moral obligations that require persons to perform or refrain from performing a certain behavior (e.g., lying, cheating, and shoplifting), thereby influencing perceived social pressures (subjective norms). Normative beliefs reflect the normative expectations of others, and the motivation to comply with these expectations [43], in order to establish a subjective norm [41].

Attempts to understand how energy-efficient appliances purchase behavior should be encouraged; the majority of the pro environmental, energy saving behavior research has focused on the role of beliefs, values, attitudes, and personal norms in shaping consumer purchase behavior towards energy-efficient appliances. However, among these studies, a less-studied or no significant work can be found on how psychological benefits, normative belief and moral obligations encourage consumer intention towards energy-efficient appliances. Therefore, to narrow the contextual and literature gap, this study has three major theoretical contributions. Firstly, this research extends the TPB to incorporate specific types of benefits (i.e., utilitarian environmental benefits and warm glow benefits) as determinants of attitude and normative belief, and moral obligations as a determinant of subjective norms, to further examine the purchase intentions of consumers in developing economies toward EEAs.

In addition, some scholars have pointed out that eco-literacy positively correlates with the attitude toward, and intentions to purchase EEAs [44,45]. In fact, past research has primarily analyzed the direct impact of eco-literacy on attitude and purchase intention, but has ignored the possible moderating role of eco-literacy. Secondly, this study, therefore, examines the moderating role of eco-literacy in the relationships between attitude, subjective norms, perceived behavioral control, and intentions to purchase EEAs.

Recent studies have focused on the determinants that affect purchasing intentions toward EEAs [19,46], and attempted to enrich the theoretical models of such intentions [2,25]. Most scholars have, however, focused on the energy-efficient purchasing intentions of samples of the wider population, so that research on differences between groups is lacking. However, some recent studies have begun to incorporate socio-demographic characteristics into their models with the aim of exploring group differences $[47,48]$. Thirdly, this study applies multi-group analysis (MGA) to deepen the structural equation model analysis, with the aim of exploring the purchase intentions of different groups of consumers toward EEAs.

\section{Literature Review}

Theoretical Background

The TPB provides a framework for examining the predictors of behavioral choices. According to the TPB, individual behavior is an outcome of behavioral intentions, whereas intentions are a function of attitude toward the behavior, subjective norms, and perceived behavioral control $[49,50]$. Fundamentally, the TPB posits that the greater the behavioral intentions, the higher the probability that a specific behavior will be enacted.

The TPB has been applied in a wide array of research areas of pro-environmental behavior, including those concerning low-consumption appliances [2,25,51-54]. However, despite considerable support, the model has received several criticisms. The major criticism refers to the necessity to include in it additional variables that would improve its 
predictive and explanatory power [55-57]. In fact, some researchers have argued that the TPB framework does not explain a sufficient proportion of the variance in intentions $[43,58]$. Ajzen $[59,60]$ acknowledged that the TPB allows for the integration of additional variables if they significantly contribute to explaining a behavior. Therefore, several researchers have suggested incorporating new variables that are relevant, in the sense that they may theoretically influence intentions to improve the explanatory power of the TPB [41,61,62]. Therefore, to attain the study contributions, the concepts of utilitarian environmental benefits, warm glow benefits, normative belief and moral obligations have been incorporated into the TPB model. To enhance the predictive power of the model for energy-efficient appliances and sustainable consumption, our studies develop on this proposition conceptually and provide the empirical evidence to validate the proposed model in the context of Pakistan.

\section{Hypothesis Development}

\subsection{Utilitarian Environmental Benefits and Attitude}

Consumers tend to be cognizant of the fact that consuming products with environmentally compatible properties offers them additional advantages compared to conventional options $[63,64]$. For example, consumers consider organic products to be tastier, owing to their perception of taste being influenced by the "organic equals healthy" association [65]. Similarly, local products are also considered to be fresher and tastier than other products [66]. Water-efficient appliances (e.g., h-axis cloth washers, dual flush toilets, and low-volume hoses) are appreciated for their water- and energy-saving potential, which reduces consumer costs [67]. Clark and Moore [68] established that people who adopt energy-saving products are considered to be more environmentally friendly, as their reduced energy consumption contributes to reducing future energy costs and reducing dependence on imported oil. Hartmann and Apaolaza-Ibáñez [38] found that utilitarian ecological benefits correlate strongly with consumer attitudes, compelling consumers to consume environmentally friendly energy products. The rationale is that using EEAs reduces air pollution from power generation, which relieves some of the pressure on natural ecosystems and improves the health of all individuals by reducing $\mathrm{CO}_{2}$ emissions. These sustainability-related advantages have been conceptualized as utilitarian environmental benefits [18]. Many other such benefits have been reported in the literature but, overall, they suggest that when consumers perceive a utilitarian benefit associated with an environmental offering, they are more likely to adopt it. The sustainability marketing literature encourages managers to associate utilitarian benefits with environmental benefits, instead of communicating only their ecological aspects $[69,70]$. Therefore, the following hypothesis is proposed:

Hypothesis 1. Utilitarian environmental benefits positively influence consumer attitudes toward energy-efficient appliances.

\subsection{Warm Glow Benefits and Attitude}

Warm-glow theory is an economic framework that describes the emotional reward that an individual may experience when enacting pure altruistic behavior-typically in the form of giving to others [71,72]. Conceptually, warm-glow giving is related to the concept of a "helper's high" [73]. Past research further shows that consumers might feel a personal sense of satisfaction when they commit themselves not only to altruistic behaviors, but also to environmental consciousness [74]. This broadening of the understanding of altruism in the sustainability area has been explored in several studies. For example, consumers may perceive an innate benefit from, and innate value in, using environmentally friendly products or services, and this sentiment has been shown to cause individual motivation that derives from a sense of commitment and a warm sense of giving [75]. Furthermore, the warm glow benefit has been extensively discussed in the green energy context, where research has shown that the anticipation of warm glow benefits has a much stronger effect on customers' willingness to pay a higher price than the perceived reduction in environ- 
mental impact [76]. Andreoni [72] emphasized that the warm glow effect resulting from "pure altruism" that is, an intrinsic motive without reciprocal expectations, is idealistic. Most often, the warm glow sentiment arises from "impure altruism," i.e., an extrinsic motive entailing reciprocal expectations [77]. EEAs save energy, and the warm glow effect may thus primarily result from a form of impure altruism owing to expected reductions in electricity consumption and, therefore, lower electricity bills. Yet, regardless of the shade of altruism, past research has shown that both stimulate warm glow effects [78] and that warm glow benefits significantly impact consumer attitudes toward green energy brands [38,79]. In other words, the perception of warm glow benefits impacts intentions through attitudes. Therefore:

Hypothesis 2. Warm glow benefits positively influence consumer attitudes toward energy-efficient appliances.

\subsection{Normative Beliefs and Subjective Norms}

Normative beliefs refer to beliefs accepted by individuals or groups as determining whether a particular behavior is correct $[80,81]$. Normative beliefs exert social pressure on people to belong to a specific group that may or may not exhibit a certain behavior [59]. The term "normative beliefs" was first used by [82], who suggested that they influence subjective norms within the TPB framework [59]. In fact, subjective norms have been considered to arise from normative beliefs [83], which according to [84], constitute a morally loaded construct that is necessary for sustainable behaviors. Several past studies have empirically assessed the relationship between normative beliefs and subjective norms $[82,85,86]$. Similar relationships have been found in scholarly research investigating pro-environmental behavior. For example, normative beliefs have been found to positively affect subjective norms in the context of environmentally friendly products [87]. However, the impact of normative beliefs on subjective norms needs to be investigated by researchers in the context of developing countries such as Pakistan. Therefore it is assumed that subjective norms to adopt energy-efficient appliances could be positively influenced by normative belief. Hence, this study proposes the following hypothesis:

\section{Hypothesis 3. Normative beliefs have a positive influence on subjective norms.}

\subsection{Moral Obligations and Subjective Norms}

A moral obligation refers to feelings within a person, arising from a sense of accountability, to execute or avoid certain behaviors [49]. Having moral obligations indicates that the individual had undertaken a commitment to behave in an environmentally conscious manner $[88,89]$. Previous studies have found empirical evidence that strongly supports the significant and positive relationships between moral obligation and environmentally friendly intention $[88,90,91]$. A moral obligation of an individual to conserve natural resources and improve the environment can stimulate the intention to purchase EEA [92]. An individual who feels a strong moral responsibility to take environmentally conscious action would often behave according to a predetermined internal normative standard as to what constitutes ethical or immoral behavior $[2,89,93]$. Past studies have empirically assessed the relationship between moral obligations and subjective norms $[85,92,94]$. However, most researchers in developing countries, such as in Pakistan, primarily ignored the link between moral obligation and subjective norm. As such, this study suggests that an individual's moral obligation could positively influence subjective norms for adopting EEAs. Therefore, this study proposes:

Hypothesis 4. Moral obligations have a positive influence on subjective norms.

\subsection{Attitude and Purchase Intention}

Attitude refers to a state of mental readiness that is learned and planned through experience, and based on the individual's reactions to objects, people, and situations to 
which they could relate [95]. In the TPB model, behavioral attitude refers to the extent to which an individual has a positive or negative evaluation of the behavior [96]. According to Ajzen [59], the more positive the attitude toward the behavior, the greater the intention to perform that behavior. In the pro-environmental literature, Wang, Fan, Zhao, Yang and $\mathrm{Fu}$ [97] provided evidence that attitude refers to the positive or negative evaluation of behavior toward environmentally friendly products. Gadenneet al. [98] found that environmental attitudes directly influence green purchases, recycling habits, and environmental household habits, without the mediation of intentions. A number of studies have undermined the importance of attitudes in energy-saving behaviors (e.g., [2,11,12]). Overall, positive attitudes toward energy saving can promote consumers' involvement in energy conservation $[99,100]$ by, for example, influencing their daily energy-saving behaviors $[25,101]$.

Hypothesis 5. Attitudes positively influence the intention to purchase energy-efficient appliances.

\subsection{Subjective Normsand Purchase Intentions}

Subjective norms refer to the degree to which people, society, or significant others approve or disapprove of a specific behavior [102]. In the TPB framework, a subjective norm refers to what important others believe the individual should do [103]. In other words, it refers to the "social pressure" that is experienced by individuals, as well as to the individual's perception of the behavior of surrounding reference groups, such as family, friends, or colleagues. These multiple layers of perception will shape a consumer's idea about what is and what is not acceptable. With the recent sustainability trend, behaviors such as switching to EEAs, newer energy sources, and environmentally friendly products, may be more positively assessed and encouraged.

Past research provides ample evidence of this psychological mechanism in the context of energy-saving behavior. According to Black et al. [104], consumers' beliefs about the benefits of energy savings may foster energy-saving behavior. Similar results were found by Ha and Janda [105] in South Korea, as well as Wang et al. [106] in China. A more recent study conducted in South Korea, based on structured questionnaires to understand the purchase intentions of Korean consumers toward EEAs, found that subjective norms had a positive effect on energy-efficient behavior [28]. Further, Wang et al. [48] emphasized that this effect also holds for purchasing intentions of EEAs. These findings have been further supported by additional studies across Asia [45,57]. However, in a study of Pakistani consumers' propensity to buy energy-saving products, Ali et al. [25] found a non-significant relationship between subjective normsand intentions to purchase energy-saving products. In addition similar results found by Tan et al. [2] found that subjective norms (SNs) do not have a significantly positive relationship with EEA purchase intention, and the lack of a relationship suggests that consumers may not be easily influenced by other people's opinions. This is surprising since Wang et al. [48] specified that, in collectivistic cultures such as those in south Asia, the effect of subjective norms on intentions to buy will probably be even stronger, because behavioral decisions are more likely to be influenced by family, friends, colleagues, and society at large. Therefore:

Hypothesis 6. Subjective norms positively influence the intention to purchase energy-efficient appliances.

\subsection{Perceived Behavioral Control and Purchase Intention}

Perceived behavioral control (PBC) refers to the extent to which individuals perceive themselves to be ready to engage in a specific form of behavior [59]. Within the context of green consumption (including purchasing), $\mathrm{PBC}$ has been investigated as an essential determinant of behavioral intentions [87,107]. In fact, stronger behavioral control is supposed to enhance consumers' willingness to perform a given behavior [59]. In the 
pro-environmental literature, $\mathrm{PBC}$ has also been defined as the perceived level of ease or difficulty of performing a specific type of behavior [108].

Past research has shown that PBC significantly impacts consumers' purchase intentions toward energy-saving products at the household level [2,25]. Counter-intuitively, Wang et al. [48] posited that behavioral control would negatively impact consumers' purchases of energy-efficient products. The rationale is that when buying energy-saving products, it is difficult to obtain relevant energy consumption information or to fully understand energy-efficient rating information, which prevents consumers from making accurate judgments and thus from feeling confident when purchasing energy-efficient products. However, this hypothesis was not supported; hence, further suggesting that PBC is strongly related to intentions to purchase EEAs, above and beyond information specificities.

Hypothesis 7. Perceived behavioral control positively affects the purchase intention toward energyefficient appliances.

\subsection{Moderating Effect of Eco-Literacy}

Environmental awareness directly impacts customers' willingness to pay for a product and is directly and indirectly linked to purchasing behavior. Studies have shown that eco-label awareness has a positive correlation with both knowledge of a product and consumers' intention to buy environment friendly products [109]. Likewise, knowledge about environmental issues could raise individuals' environmental awareness, and so promote a positive behavior toward green or environmentally friendly products [110]. In terms of eco-literacy, if consumers are well informed about environmental problems, they will be inclined to make purchase decisions based on rational criteria, rather than feelings. Generally, more eco-literacy will lead to stronger purchase intentions for environmentally friendly products because it implies better understanding of environmental symbols, concepts, benefits, and consequences. Therefore, the explanatory power of attitude would be enhanced. With less eco-literacy, consumers would be expected to make their purchase decisions based on their feelings or emotions, so the explanatory power of attitude would decline. Therefore, eco-literacy is expected to play an important role in the relationship between attitude and purchase intention. Based on the above discussion, this study proposes the following hypothesis:

Hypothesis 8. Eco-literacy moderates the relationship between attitude and purchase intention toward energy-efficient appliances.

Subjective norms reflect the perceived social pressures an individual feels to engage in certain kinds of behavior and are determined by a set of beliefs related to cultural values [111]. In modern society, individuals are closely related to society, which influences their pro-environmental behavior [19]. In Pakistani society, the mainstream cultureis collectivist, and social outcomes play a role in consumers' purchasing decision processes [19]. If consumers are more environmentally conscious and literate, they are more likely to rely on themselves to make a purchase decision than to take suggestions from their friends, family members, co-workers, and other members of reference groups. Therefore, we assume that consumers' increased knowledge would reduce the explanatory power of subjective norms. However, when consumers have less eco-knowledge (eco-literacy), they are more likely to rely on suggestions and endorsements from their social circles when making decisions, owing to their low confidence. Therefore, the authors assume that a low level of consumer knowledge would enhance the power of subjective norms to explain purchase intention. Hence, the following hypothesis is postulated:

Hypothesis 9. Eco-literacy significantly moderates the relationship between subjective norms and purchase intention toward energy-efficient appliances. 
Environmentally friendly products, such as EEAs, often require more time, money, and enthusiasm for their purchase, before their consumption can be considered an effective way to solve environmental problems $[19,112,113]$. People with environmental knowledge can better understand the value of environmentally friendly products, and it is more likely that their knowledge will influence their buying behavior [114]. In contrast, people with less environmental knowledge are not familiar with environmentally friendly products and are not motivated to solve environmental problems [115]. More eco-literacy increases consumers' perceived behavioral control toward the purchase intention of environmentally friendly products. Conversely, consumers with low eco-literacy experience less perceived behavioral control toward the purchase intention of products.

Hypothesis 10. Eco-literacy moderates the relationship between perceived behavioral control and purchase intention for energy-efficient appliances.

Drawing on the arguments and conceptual developments given above, Figure 1 shows an illustrative framework of our hypothetical relationships.

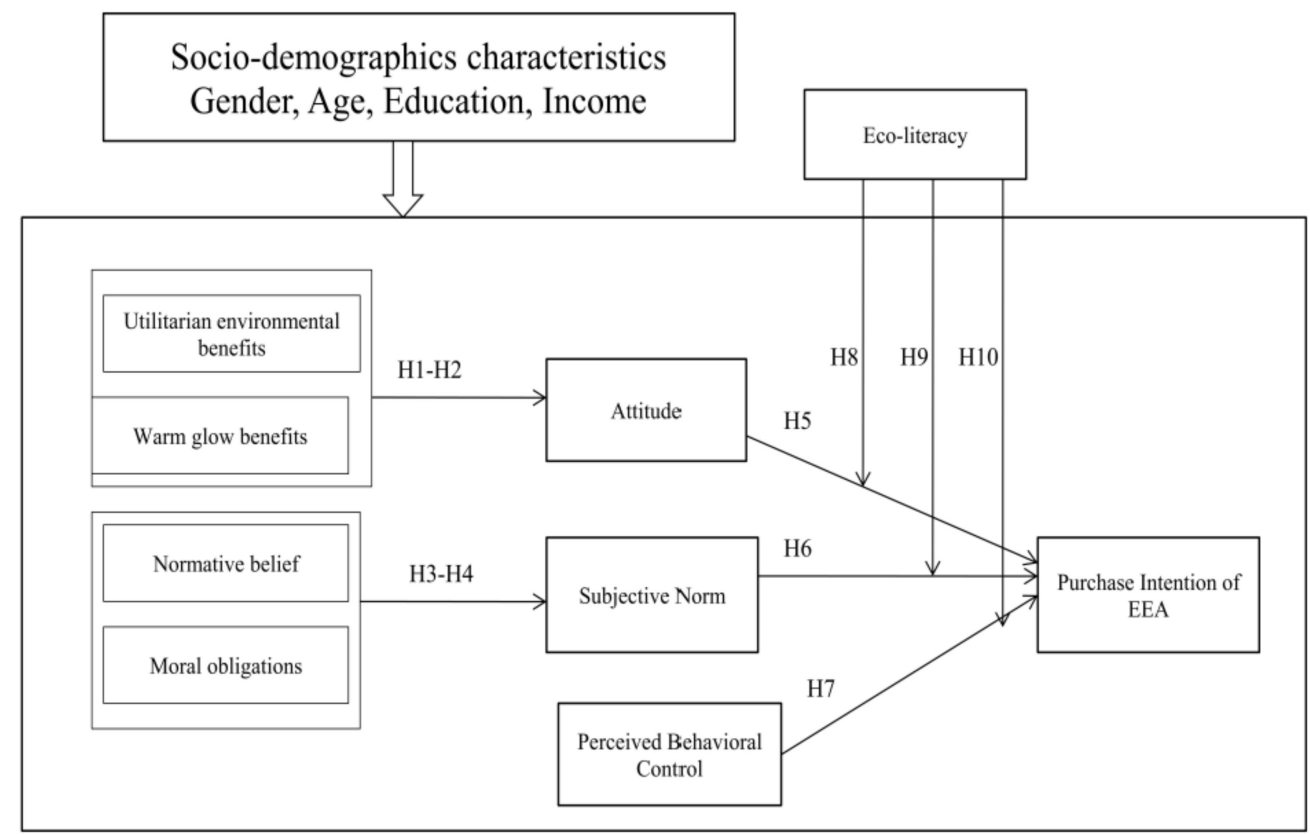

Figure 1. Conceptual hypothesized research model (theory of planned behavior (TPB), extended).

\section{Materials and Methods}

\subsection{Procedure and Participants}

A quantitative methodological approach using a survey questionnaire was used to analyze the purchase of EEAs at the household level. The questionnaire was divided into two sections. The first section contained the construct measurement items and their corresponding measurement scales. The second part consisted of demographic variables, as reported in Table 1. 
Table 1. Respondent demographics.

\begin{tabular}{ccc}
\hline & Frequency & Percentage \\
\hline Gender & 346 & \\
Female & 327 & $51.40 \%$ \\
Male & 673 & $48.60 \%$ \\
Total & & $100 \%$ \\
Age & 245 & \\
$18-24$ & 260 & $36.40 \%$ \\
$25-34$ & 88 & $38.60 \%$ \\
$35-44$ & 80 & $13.10 \%$ \\
$>45$ & 673 & $11.90 \%$ \\
Total & 176 & $100 \%$ \\
Education & 229 & $26 \%$ \\
College degree & 268 & $34 \%$ \\
Undergraduate & 673 & $40 \%$ \\
Master's or PhD degree & & $100 \%$ \\
Total & 211 & \\
Income level & 331 & $31.40 \%$ \\
Less than or equal to 50,000 Rs & 131 & $49.20 \%$ \\
50,001-99,000 Rs & 673 & $19.50 \%$ \\
Greater than or equal & & $100 \%$ \\
to100,000 Rs & &
\end{tabular}

The data were collected through face-to-face interviews from November 2019 to December 2019 in diverse regions of Karachi, Pakistan. Karachi is the capital of Sind Province and the economic hub of Pakistan. The respondents declared their consent before participating in the study. The data were collected from 10 different leading stores in Karachi. The demand for efficient household appliances (i.e., washing machines, air conditioners, refrigerators, cooling fans, and water pumps) has notably surged in metropolitan cities. The convenience sampling technique was employed, because it is appropriate when it is difficult to obtain a complete sampling frame. This type of sampling is suitable, because it permits a theoretical generalization of the findings. A total of 800 questionnaires were distributed, of which 690 were returned. Finally, after primary screening, 673 questionnaires were found to be useful for the present study.

\subsection{Measurements}

Construct measurement items were adopted and/or adapted from the literature. The TPB constructs were all measured with a three-item scale. The items reflecting attitude toward EEAs were adapted from Ha and Janda [116], and those measuring subjective norm were adapted from Nguyen et al. [117], while PBC items were derived from Alam et al. [118]. Items pertaining to warm glow benefits and utilitarian environmental benefits were adapted from Hartmann andlbáñez [38], whereas those items measuring normative beliefs originated in Yadav and Pathak [83], moral obligation in Mamun et al. [41] and eco-literacy adapted from Mamun et al. [41]. Finally, purchase intentions of EEAs were measured with a four-item scale adapted from Wang et al. [48] (see Appendix A).

The demographics details of the respondents are listed in Table 1 . The total number of valid responses was 673 , comprising 346 from females (51.40\%) and 327 from males $(48 \%)$. There were $245(36.40 \%)$ respondents aged between $18-24$ years, 260 respondents $(38.60 \%)$ aged between $25-34$ years, 88 respondents $(31.80 \%)$ aged between $25-44$ years and 80 respondents $(11.90 \%)$ who were older than 45 years. In terms of education, 176 $(26 \%)$ had a college degree, $229(34 \%)$ had an undergraduate degree, and $268(40 \%)$ had a Master's or PhD degree. In terms of income level, around $331(49.20 \%)$ respondents had a monthly income between 50,001 and 100,000, while 221 (31.06\%) had a monthly income below 50,000 PKR, and 131 (19\%) had monthly income higher than RS 100,000. 


\section{Results}

This section reports the partial least squares structural equation model (PLS-SEM), which was performed to test the conceptual model using both SPSS and SmartPLS 3.0. The analysis was conducted in two stages. First, the measurement model was evaluated with SPSS and SmartPLS to assess both the validity and reliability of the abovementioned measurement scales. Second, the structural model was assessed to test the hypothesized relationships, following the two-stage analytical procedure of SmartPLS.

In addition, PLS-SEM has the added advantage of estimating the measurement model and is suitable for performing MGA to analyze group differences. The MGA approach can clarify whether there are differences in the hypothetical relationships between different groups. Previous studies have used MGA to show the differences in factors between groups $[119,120]$.

\subsection{Measurement Model}

Convergent validity was determined by factor loadings, composite reliability (CR), and average variance extracted (AVE), as shown in Table 2. More specifically, all factor loadings ranged from 0.647 to 0.906 , which ensures convergent validity based on the criteria proposed by [121]. In addition, all CR and AVE values ranged from 0.816 to 0.924 , and from 0.600 to 0.762 , respectively, which further ensures convergent validity as well as reliability, according to the criteria proposed by Hair et al. [81]

Discriminant validity was measured using the criteria proposed by Fornell and Larcker [122]. The square root of the AVE for a specific indicator must be larger than all of the correlations of that construct with any other construct. As shown in Table 3, all the constructs met this criterion. Similarly, the HTMT ratio was assessed using the HTMT.90 criteria [123]. Table 3 showed that the HTMT values for all construct values are below the 0.90 limit, which met the HTMT.90 criteria. Therefore, the requirements of discriminant validity are met for each construct.

Table 2. Reliability and validity results.

\begin{tabular}{|c|c|c|c|c|}
\hline Constructs & Items & Loading & CR & AVE \\
\hline \multirow{3}{*}{$\begin{array}{c}\text { Utilitarian } \\
\text { environmental } \\
\text { benefits }\end{array}$} & UEB1 & 0.840 & 0.905 & 0.762 \\
\hline & UEB2 & 0.876 & & \\
\hline & UEB3 & 0.870 & & \\
\hline \multirow[t]{3}{*}{$\begin{array}{l}\text { Warm glow } \\
\text { benefits }\end{array}$} & WGB1 & 0.840 & 0.897 & 0.744 \\
\hline & WGB2 & 0.876 & & \\
\hline & WGB3 & 0.870 & & \\
\hline \multirow[t]{3}{*}{ Normative belief } & NB1 & 0.747 & 0.882 & 0.715 \\
\hline & NB2 & 0.883 & & \\
\hline & NB3 & 0.889 & & \\
\hline \multirow[t]{3}{*}{$\begin{array}{c}\text { Moral } \\
\text { obligations }\end{array}$} & MB1 & 0.906 & 0.893 & 0.736 \\
\hline & MB2 & 0.821 & & \\
\hline & MB3 & 0.898 & & \\
\hline \multirow[t]{3}{*}{ Eco-literacy } & ECL1 & 0.811 & 0.871 & 0.692 \\
\hline & ECL2 & 0.834 & & \\
\hline & ECL3 & 0.850 & & \\
\hline \multirow[t]{3}{*}{ Attitude } & AT1 & 0.878 & 0.886 & 0.722 \\
\hline & AT2 & 0.862 & & \\
\hline & AT3 & 0.810 & & \\
\hline
\end{tabular}


Table 2. Cont.

\begin{tabular}{ccccc}
\hline Constructs & Items & Loading & CR & AVE \\
\hline Subjective & SN1 & 0.647 & 0.816 & 0.600 \\
norms & SN2 & 0.866 & & \\
& SN3 & 0.795 & & \\
& & & 0.818 & \\
Perceived & PBC1 & 0.801 & & \\
behavioral & & & \\
control & PBC2 & 0.742 & 0.752 \\
& PBC3 & 0.780 & \\
\hline Purchase & PI1 & 0.790 & & \\
intention & PI2 & 0.886 & & \\
& PI3 & 0.895 & & \\
& PI4 & 0.896 & & \\
\hline
\end{tabular}

Notes: UEB = utilitarian environmental benefits; $\mathrm{WGB}=$ warm glow benefits; $\mathrm{NB}=$ normative beliefs; $\mathrm{MB}=$ moral obligations; $\mathrm{EL}=$ eco-literacy; $\mathrm{AT}=$ attitude; $\mathrm{SN}=$ subjective norm; $\mathrm{PBC}=$ perceived behavioral control; $\mathrm{PI}=$ purchase intention.

\subsection{Structural Model Evaluation}

Given that the measurement model was both reliable and valid, the second step of the analytical procedure involved the evaluation of the structural model. In evaluating the structural model, both the beta coefficients and the $t$-statistics were considered in order to assess both the directionality and significance of the hypothesized paths. Furthermore, $R^{2}$ values estimated the proportion of variance explained in each predicted construct of the model [81].

Table 3. Correlation matrix and heterotrait-monotrait ratio (HTMT) matrix.

\begin{tabular}{|c|c|c|c|c|c|c|c|c|c|}
\hline & AT & EL & PBC & PI & SN & UEB & WGB & MB & NB \\
\hline Attitude & 0.850 & & & & & & & & \\
\hline $\begin{array}{l}\text { Eco-literacy } \\
\text { Perceived }\end{array}$ & 0.561 & 0.832 & & & & & & & \\
\hline $\begin{array}{l}\text { Perceived } \\
\text { behavioral } \\
\text { control }\end{array}$ & 0.555 & 0.602 & 0.775 & & & & & & \\
\hline $\begin{array}{l}\text { Purchase } \\
\text { intention }\end{array}$ & 0.649 & 0.408 & 0.573 & 0.867 & & & & & \\
\hline $\begin{array}{l}\text { Subjective } \\
\text { norms }\end{array}$ & 0.553 & 0.518 & 0.523 & 0.465 & 0.775 & & & & \\
\hline $\begin{array}{c}\text { Utilitarian } \\
\text { environmental } \\
\text { benefits }\end{array}$ & 0.678 & 0.589 & 0.573 & 0.718 & 0.501 & 0.873 & & & \\
\hline $\begin{array}{c}\text { Warm-glow } \\
\text { benefits }\end{array}$ & 0.625 & 0.567 & 0.585 & 0.561 & 0.489 & 0.624 & 0.862 & & \\
\hline $\begin{array}{c}\text { Moral } \\
\text { obligations }\end{array}$ & 0.635 & 0.658 & 0.609 & 0.633 & 0.444 & 0.762 & 0.693 & 0.858 & \\
\hline $\begin{array}{l}\text { Normative } \\
\text { belief_ }\end{array}$ & 0.654 & 0.651 & 0.547 & 0.494 & 0.623 & 0.632 & 0.660 & 0.692 & 0.846 \\
\hline
\end{tabular}


Table 3. Cont.

\begin{tabular}{|c|c|c|c|c|c|c|c|c|c|}
\hline & AT & EL & PBC & PI & SN & UEB & WGB & MB & NB \\
\hline \multicolumn{10}{|c|}{ Heterotrait-Monotrait Ratio (HTMT) Matrix } \\
\hline Attitude & & & & & & & & & \\
\hline Eco-literacy & 0.704 & & & & & & & & \\
\hline $\begin{array}{l}\text { Perceived } \\
\text { behavioral } \\
\text { control }\end{array}$ & 0.751 & 0.816 & & & & & & & \\
\hline $\begin{array}{l}\text { Purchase } \\
\text { intention }\end{array}$ & 0.764 & 0.488 & 0.717 & & & & & & \\
\hline $\begin{array}{l}\text { Subjective } \\
\text { norms }\end{array}$ & 0.774 & 0.739 & 0.791 & 0.601 & & & & & \\
\hline $\begin{array}{c}\text { Utilitarian } \\
\text { environmental } \\
\text { benefits }\end{array}$ & 0.819 & 0.724 & 0.738 & 0.828 & 0.671 & & & & \\
\hline $\begin{array}{l}\text { Warm-glow } \\
\text { benefits }\end{array}$ & 0.764 & 0.703 & 0.766 & 0.654 & 0.673 & 0.746 & & & \\
\hline $\begin{array}{c}\text { Moral } \\
\text { obligations }\end{array}$ & 0.781 & 0.823 & 0.799 & 0.742 & 0.627 & 0.641 & 0.842 & & \\
\hline $\begin{array}{l}\text { Normative } \\
\text { belief }\end{array}$ & 0.829 & 0.827 & 0.749 & 0.604 & 0.843 & 0.789 & 0.829 & 0.880 & \\
\hline
\end{tabular}

Note: UEB = utilitarian environmental benefits; WGB = warm glow benefits; NB = normative beliefs; $\mathrm{MB}=$ moral obligations; $\mathrm{EL}=$ eco-literacy; $\mathrm{AT}=$ attitude; $\mathrm{SN}=$ subjective norm; $\mathrm{PBC}=$ perceived behavioral control; PI = purchase intention.

The R2 values estimated for the endogenous variables, attitude, subjective norms, and purchase intentions of EEAs were 0.526, 0.389, and 0.495, respectively. The addition of benefits, therefore, led to the explanation of a high share of the variance in the attitude construct. More generally, the model explains more than half of the variance in the dependent variable of intentions, which in the social sciences context, is a high proportion.

Table 4 shows the standardized path coefficients, $t$-values, and results. Factors affecting attitude, such as utilitarian environmental benefits $(\beta=0.471, p \leq 0.01)$, and warm glow benefits $(\beta=0.331, p \leq 0.01)$, both had a significant positive impact on attitude. In terms of subject norms, normative belief $(\beta=0.606, p \leq 0.01)$ had a significant positive impact on subjective norms, while moral obligations $(\beta=0.024, p \geq 0.05)$ had a non-significant impact on subjective norms. Concerning the components of the theory of planned behavior, based on the results derived from the data set, our study found that attitude ( $\beta=0.480, p$ $\leq 0.01$ ), subjective norms $(\beta=0.081, p \leq 0.01)$, and perceived behavioral control $(\beta=0.324$, $p \leq 0.01$ ) had a significant impact on purchase intention of EEAs. Therefore, hypotheses $\mathrm{H} 1, \mathrm{H} 2, \mathrm{H} 3, \mathrm{H} 5, \mathrm{H} 6$, and $\mathrm{H} 7$ are supported, and H4 is rejected. Figure 2 shows the path coefficients and degree of influence. 
Table 4. Hypothesized direct and moderating relationship assessment.

\begin{tabular}{|c|c|c|c|}
\hline Hypothesis & Beta & T-Value & Status \\
\hline $\begin{array}{l}\text { H1: Utilitarian Environmental } \\
\text { benefits } \rightarrow \text { Purchase Intention }\end{array}$ & 0.471 & $11.151^{* *}$ & Accepted \\
\hline $\begin{array}{l}\text { H2: Warm glow benefits } \rightarrow \\
\text { Purchase Intention }\end{array}$ & 0.331 & $7.492 * *$ & Accepted \\
\hline $\begin{array}{l}\text { H3: Normative belief } \rightarrow \\
\quad \text { Purchase Intention }\end{array}$ & 0.606 & $16.357^{* *}$ & Accepted \\
\hline $\begin{array}{l}\text { H4: Moral obligation } \rightarrow \\
\quad \text { Purchase Intention }\end{array}$ & 0.024 & 0.626 & Rejected \\
\hline $\begin{array}{l}\text { H5: Attitude } \rightarrow \text { Purchase } \\
\text { Intention }\end{array}$ & 0.480 & $13.535^{* *}$ & Accepted \\
\hline $\begin{array}{l}\text { H6: Subjective norm } \rightarrow \text { Purchase } \\
\text { Intention }\end{array}$ & 0.081 & $2.543^{* *}$ & Accepted \\
\hline $\begin{array}{l}\text { H7: Perceived behavioral control } \\
\quad \rightarrow \text { Purchase Intention }\end{array}$ & 0.324 & $9.215^{* *}$ & Accepted \\
\hline $\begin{array}{c}\text { H8: Attitude } \times \text { Eco-literacy } \rightarrow \\
\text { Purchase Intention }\end{array}$ & 0.510 & $14.28^{* *}$ & Accepted \\
\hline $\begin{array}{l}\text { H9: Subjective norms } \times \\
\text { Eco-literacy } \rightarrow \text { Purchase } \\
\text { Intention }\end{array}$ & 0.141 & $4.293 *$ & Accepted \\
\hline $\begin{array}{l}\text { H10: Perceived behavioral } \\
\text { control } \times \text { Eco-literacy } \rightarrow \\
\text { Purchase Intention }\end{array}$ & 0.017 & 0.772 & Rejected \\
\hline
\end{tabular}

Notes: ${ }^{*}$ denotes $p \leq 0.05 ;{ }^{* *}$ denotes $p \leq 0.01$.

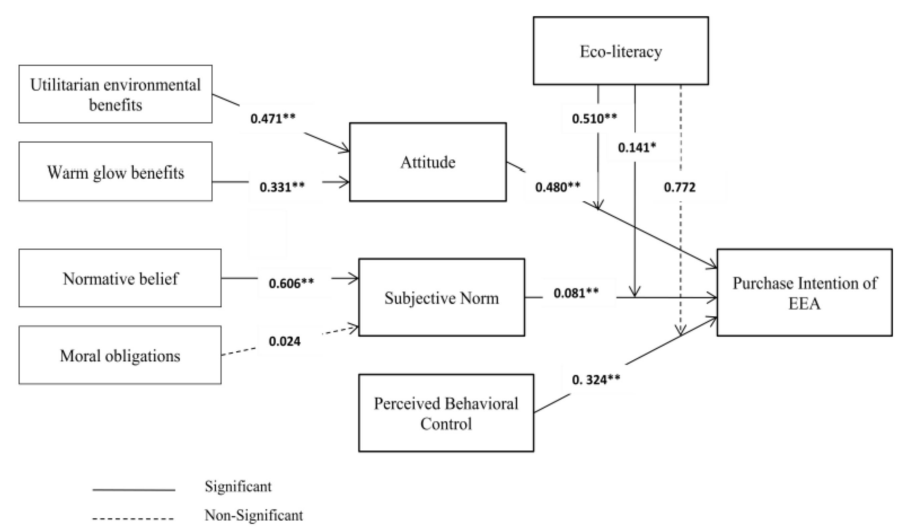

Figure 2. Hypothesis model with moderator. * denotes $p \leq 0.05$; ${ }^{* *}$ denotes $p \leq 0.01$.

Based on the results, it was found that eco-literacy increases the relationship between attitude and purchase intention of EEAs $(\beta=0.510, p \leq 0.01)$, and that the interaction of eco-literacy in the relationship between subjective norms, and that the interaction of eco-literacy in the relationship between subjective norms and purchase intention of EEAs actually strengthens the relationship between subjective norms and purchase intention of EEAs $(\beta=0.141, p \leq 0.05)$. Finally, the interaction of eco-literacy in the relationship between perceived behavioral control and EEAs $(\beta=0.017, p \geq 0.05)$ had a non-significant effect. Hence H8, and H9 are accepted, and H10 is rejected.

\subsection{Multi-Group Analysis}

An MGA was used to examine the effects of the variables between the different groups. The categorical variables were age, gender, income level, and level of education. According to reference [81], there are four approaches to analyzing these groups: the parametric approach, considered the most liberal; the permutation and confidence-based approaches, which are the most conservative; and the strictest of all, the Henseler's multi-group ap- 
proach. For the latter, Henseler [124] proposed an even more developed extension, the PLS-MGA approach (multi-group analysis), which indicates significant differences between groups when these are below 0.05 or above 0.95 . In this study, we used a percentile bootstrapping method to examine the differences between the groups. The results showed a significant intergroup difference with a $5 \%$ margin of error when the $p$-value was greater than $95 \%$ or less than $5 \%$. In particular, the percentile below $5 \%$ indicates that the bootstrapping results of group A are higher than that of group B. The percentile above $95 \%$ shows that group $B$ results are higher than group A.

The estimated paths for each group are shown in Table 5. The results of the PLS-MGA $p$-value show significant group differences. For gender, H6 $(p=0.986>0.95)$, differed significantly, indicating that the relationship between subjective norms and purchase intention was stronger for the female group than for the male group. For age, H7 $(p=0.04<0.05)$, differed significantly, indicating that the relationship between perceived behavioral control and purchase intention was stronger in the young group than in the older group. For education, H1 ( $p=0.968>0.95)$ differed significantly, showing that the relationship between attitude and purchase intention is stronger for the highly educated group than for the less-educated group. For income, H3 $(p=0.017<0.05)$ differed significantly, indicating that the relationship between normative beliefs and subjective norms was stronger in the low-income group than in the high-income group.

Table 5. Results of structural equation model (SEM)-multi-group analysis (MGA).

\begin{tabular}{|c|c|c|c|c|c|c|c|}
\hline & H1 & H2 & H3 & H4 & H5 & H6 & H7 \\
\hline \multicolumn{8}{|l|}{ Gender } \\
\hline Male & 0.520 & 0.375 & 0.583 & 0.001 & 0.497 & 0.057 & 0.028 \\
\hline Female & 0.403 & 0.308 & 0.645 & 0.034 & 0.454 & 0.056 & 0.303 \\
\hline Diff & 0.117 & 0.067 & -0.062 & -0.033 & 0.043 & 0.001 & -0.275 \\
\hline PLS & & & & & & & \\
\hline MGA & 0.189 & 0.469 & 0.404 & 0.674 & 0.567 & 0.986 & 0.491 \\
\hline Value & & & & & & & \\
\hline \multicolumn{8}{|l|}{ Age } \\
\hline Young & 0.451 & 0.345 & 0.566 & 0.050 & 0.044 & 0.073 & 0.286 \\
\hline Elder & 0.494 & 0.319 & 0.644 & 0.008 & 0.011 & 0.051 & -0.203 \\
\hline Diff & -0.043 & 0.026 & -0.078 & 0.042 & 0.032 & 0.022 & 0.489 \\
\hline PLS & & & & & & & \\
\hline MGA & 0.606 & 0.768 & 0.295 & 0.579 & 0.887 & 0.727 & 0.004 \\
\hline Value & & & & & & & \\
\hline \multicolumn{8}{|c|}{ Education } \\
\hline Low & 0.353 & 0.409 & 0.623 & -0.068 & 0.554 & 0.082 & 0.294 \\
\hline High & 0.494 & 0.31 & 0.602 & 0.052 & 0.46 & 0.057 & 0.367 \\
\hline Diff & 0.141 & 0.099 & 0.021 & -0.12 & 0.094 & 0.025 & -0.073 \\
\hline PLS & & & & & & & \\
\hline MGA & 0.968 & 0.335 & 0.784 & 0.214 & 0.305 & 0.735 & 0.471 \\
\hline Value & & & & & & & \\
\hline \multicolumn{8}{|l|}{ Income } \\
\hline Low & 0.430 & 0.369 & 0.145 & -0.015 & 0.456 & 0.157 & 0.323 \\
\hline High & 0.482 & 0.323 & -0.019 & 0.028 & 0.483 & 0.045 & 0.360 \\
\hline Diff & -0.052 & 0.046 & 0.164 & -0.043 & -0.027 & 0.112 & -0.037 \\
\hline PLS & & & & & & & \\
\hline MGA & 0.644 & 0.676 & 0.017 & 0.643 & 0.791 & 0.165 & 0.721 \\
\hline Value & & & & & & & \\
\hline
\end{tabular}

Note: Bold font: Partial least squares (PLS)-MGA $p$-value below 5\% and above 95\% indicates significant values. Diff $=$ path Coefficient Differences. 


\section{Discussion and Conclusions}

This study finds that utilitarian environmental benefits and warm glow benefits have significant positive effects on consumers' attitude toward EEAs. Hence, the findings support previous literature that utilitarian environmental and warm glow benefits positively enhance consumers' confidence in green products $[38,76,125]$. The findings from this study suggest that the perception of utilitarian environmental benefits (environmental excellence and energy saving) among consumers is associated with EEAs. A positive consumer attitude toward EEAs is due to the superior environmental functionality that they can deliver. Additionally, another benefit related to altruism, called warm glow benefits, was also found to be significant, confirming past research $[38,74]$. The results suggest that the "feel-good" sentiment or "helper's high" effect [73] that consumers anticipate they will experience when enacting an altruistic behavior-even if it their altruism is impure [71,72] may also occur in the case of a pro-environmental behavior such as an EEA purchase. In other words, warm glow benefits motivate consumers to pay premium prices for EEAs to feel moral satisfaction. In sum, the high degree of variance observed in attitudes results from the compound perception of both superior environmental functionality benefits and moral satisfaction benefits that EEAs can deliver. In terms of subjective norms, moral obligation does not have a significant effect on subjective norms. According to Reference [49], moral values are essential to predict negative behaviors such as lies, fraud, and stealing. Purchasing EEAs is a positive and publicly acceptable behavior that is not reliant on moral obligations. The results of this study, therefore, suggest that consumers' intention to purchase EEAs, being positive and rational, may not have to be driven by their moral commitment to social acceptance. Normative beliefs have positive effects on subjective norms, which are similar to past studies $[81,85,126]$. This finding suggests that consumers these days are more aware of environmental issues and ecology; therefore, normative beliefs shape Pakistani consumers' subjective norms that society expects them to take pro-environmental actions.

The results support the theory of planned behavior through a significant positive relationship between TPB constructs of attitude toward EEAs, subjective norms, perceived behavior control, and intention to purchase EEAs. Attitude has the biggest impact on intention to purchase EEAs, which indicates that consumers in Pakistan have constructive attitudes toward EEAs, and would generally intend to buy such appliances. This finding is in line with previous studies $[2,25,100,116]$. Perceived behavioral control follows attitude in terms of the impact on intention to purchase EEAs. In line with consumers in other parts of the world $[2,25,100,127]$, Pakistani consumers are more likely to purchase EEAs when they feel that this specific act of purchase is not extremely difficult for them, and thus feel that they are ready to engage in that purchase behaviour. Among the TPB variables, subjective norms tend to exert the weakest impact on intentions. This was further confirmed by the weak effect size. This is in line with previous studies conducted in Asian contexts $[45,57,120]$. It is also consistent with some form of common sense, suggesting that consumers' purchasing decisions could easily be influenced by the opinions of, and suggestions from, those who are close to them, such as family and, especially, friends. The results, however, contradict some past studies that found a non-significant effect of subjective norm on intentions [25,117]. Altogether, these results may hint at the fact that, in developing economies, social pressure to consume sustainable products may not be sufficiently prevalent to influence purchasing decisions. Jayanti and Gowda [128] commented on this issue by emphasizing that emerging markets face the following dilemma: fast urbanization to raise living standards poses a concomitant threat to the environment. In other words, the economic criterion tends to prevail over the environmental one. Hence, since there is no strong social norm, it cannot influence consumers as much as other variables.

Our study found that consumers' eco-literacy, that is, their knowledge of the environment, strengthens the relationship between attitude and intention to purchase EEAs. This finding is aligned with previous literature that suggested that eco-literacy influences consumer attitude and purchase intention for environmentally friendly products [41,129]. Eco-literacy actually induces consumers to look for products that have a less negative 
impact on the environment, and consumers' knowledge of the environment helps their thinking process to become a belief that shapes their attitude toward the environment. Knowledge is a very important base for the formation of people's actions, because they will act in accordance with their knowledge. Eco-literacy significantly moderates the relationship between subjective norms and purchase intention of EEAs; this finding interestingly opposes the assumption made by previous authors that high eco-literacy will reduce the explanatory power of subjective norms to influence consumers' purchase intention. Further, it can be deduced that people in Pakistan give more importance to maintaining group ideology and preserving in-group harmony. A previous study confirms this, as it found that people in Pakistan who hold strong social group values and beliefs stress collective interests over individual ones [130]. However, our study finds that environmental knowledge plays a role as a moderator between subjective norms and purchase intentions. Further, it finds that eco-literacy does not have an interaction relationship between perceived behavioral control and purchase intention of EEAs. The existing literature on this situation, such as [61,131], clarified that people from collectivist countries could face strong pressure from others and are willing to over-ride their own opinions or perceptions. As a result, they do not have a high level of autonomy and confidence in making decisions about purchasing novel products. It can be confidently asserted that the collectivist values of Pakistani consumers nullify the moderating effect of eco-literacy between perceived behavior control and purchase intention.

The results of this study show significant differences in purchasing intention due to differences in demographic characteristics such as gender, age, education, and income level. For the gender groups, the relationship between subjective norms and purchase intentions of EEAs, utilitarian environmental benefits, and attitudes toward EEAs pass the significance test for female groups, which is consistent with past studies [61,132]. In Pakistan, women are mostly the caretakers of the home, and men work to support the families. Female children are assumed to take care of household chores, while women stay at home and are closer to family members, who are more likely to be influenced by others. Therefore, it is common in Pakistan, especially in urban areas, for the women who manage monthly household budgets to buy products that consume less electricity, because of Pakistan's high electricity charges. In terms of age, our results show that perceived behavioral control and purchase intention of EEAs have passed the significance test for the young people's group. This shows that young people have more knowledge, resources, and confidence, which encourage them to buy pro-environmental products such as EEAs. In terms of education, the relationship between attitude and purchase intention of EEAs passes the significance test for highly educated people. This shows that highly educated people have a stronger attitude toward purchase intention of EEAs than less-educated people because they are more knowledgeable and informed about environmental issues such as global warming, $\mathrm{CO}_{2}$ emissions, and their impact on people's lives. Our findings support those of previous studies; more-educated consumers are more likely to be more environmentally friendly than less-educated consumers because of their better understanding of and involvement in, environmental issues [133]. From the perspective of income level, the relationship between normative belief and subjective norms passes the significant test for low-income level people. This indicates that the normative belief has a strong impact on subjective norms in the low-income level group because energy prices have increased rapidly in Pakistan; people in the low-income group, therefore, assign more weight to the opinions of their friends and family, who encourage them to look for pro-environmental products such as EEAs that consume less energy.

\subsection{Theoretical Contributions}

This study also makes theoretical contributions to the extant literature on intentional behavior and topical research on EEAs in several ways. First, it extends and enriches the literature by focusing on EEAs and providing empirical evidence concerning the factors affecting purchase intention, which remains a less-researched study in the context of devel- 
oping economies. In addition, in contrast to similar studies that extend the TPB to examine EEA purchases from a technology readiness perspective (e.g., [25], this study proposes that a key to unlocking pro-environmental behavior is to have consumers perceive the benefits arising from such behavior. Another aspect refers to the role played by consumers' stronger environmental awareness in the form of normative beliefs that foster pro-environmental behavior. The study, therefore, extends the TPB framework meaningfully, by investigating some key variables that have remained largely unexplored until now, such as warm glow benefits, utilitarian environmental benefits, normative beliefs, and moral obligations. While utilitarian environmental benefits, warm glow benefits, and self-expressive benefits have been incorporated as predictors of attitudes toward EEAs, this study's second postulate places normative beliefs and moral obligation as an antecedent to the subjective norm. The theoretical implication of this study arises from the fact that it empirically supports TPB Ajzen [59] in terms of energy-efficient appliances adoption in developing economy Pakistan, thereby increasing its scope and applicability.

Second, Pakistan is a potentially promising market for green and environmentally friendly products because of its pro-environmental population and rising economy. The purpose of this research was to gain deeper insights into consumers' intentions to purchase EEAs in that specific developing market. The contribution of this study arises from its findings concerning EEAs consumed by consumers in Pakistan that support, empirically, the TPB [126], which expands the scope and benefits of that approach.

Third, this study investigates the moderating role of eco-literacy in the relationship between attitude, subjective norms, perceived behavioral control, and purchase intention of EEAs. Past studies have incorporated eco-literacy as an antecedent to attitude and purchase intention for environmentally friendly products and behavior [44] According to the results of this study, eco-literacy could also be regarded as a moderator in the theory of planned behavior to investigate purchase intention and behavior.

Fourth, the result of this study found strong group aviation in the purchase intention of EEA, consistent with the results of past studies using multi group analysis $[47,120]$. The combination of PLS SEM and MGA method is very useful because it only examine the behavior but also quantify the variation in the behavior of different groups [134].

\subsection{Managerial Implications}

The findings of this study have significant implications for marketers of EEAs. They suggest that utilitarian environmental benefits and warm glow benefits both potentially enhance consumers' attitudes toward EEAs and increase their purchase intention, encouraging the adoption of EEAs. Marketers should, therefore, promote the environmental benefits of EEAs, such as preventing greenhouse gas emissions, reducing people's carbon footprint, improving the quality of life, and warm glow benefits through appropriate advertising messages that appeal to the audience's sense of community, stressing that, when they purchase EEAs they can "feel good while doing good"—socially and environmentally.

Our study also suggests that eco-literacy plays an important role in consumers' intentions to purchase EEAs. Therefore, marketers and firms should provide environmental knowledge through social media platforms and electronic media, and provide information about eco-labels and signs, and the benefits of consuming pro-environmental products. This would ultimately enhance consumers' understanding of environmental issues. As a result, consumers would look for products such as EEAs that have a less negative impact on the environment and sustainability. Consumers currently lack the appropriate knowledge, or have a skeptical attitude toward product information; therefore, enterprises should emphasize the environmental benefits of products to consumers. As well, companies should introduce new products that function better, cost less, and are technologically innovative.

Practically, this study provides new insights by extending the TPB to investigate empirically the purchase intention of EEAs in an Asian developing economy; that is, Pakistan. This could help global businesses better understand Pakistan's consumers and the country's green marketing potential. In addition, the results from testing the 
conceptual model can help managers understand the relative importance of the factors that contribute to consumer purchase intention. From a consumer perspective, the goal of EEA is to decrease the amount of its energy consumption, and it thus has a socio-economic impact on consumers directly and indirectly: when marketers create impressive and better marketing programs and influence more consumers to buy EEAs more energy will be saved, which means lower electricity bills. Consumers and society as a whole must have a better living environment, as reduced energy consumption is better for the environment.

\subsection{Limitations and Future Research Directions}

First, this study focused on consumers' intention to purchase EEAs; future research on actual behaviors can be conducted by comparing people's intentions with their actual behaviors, so as to effectively understand how intentions are transformed into those behaviors. Second, the current research mainly focuses on EEAs; future research should observe the perceptions of consumers in other areas of sustainability, such as the consumption of biodegradable products or green vehicles. Third, the participants in this research were mainly residents of a single city in Pakistan, namely Karachi. It is important that future studies collect data from different cities in Pakistan, and they could also increase the sample size to enhance the generalizability of their findings. In addition, changes in attitudes and behavioral intentions of consumers over time could be observed by carrying out a longitudinal study. Fourth, although the EEA's purchase intention was examined in this study using a questionnaire survey, however observation techniques should be used as well in similar studies. The use of observation techniques can further improve understanding of pro-environmental behavior in which a more rational and ingenuous behavior can be examined. Fifth, it is suggested that in the future, researchers include a sub-cultural dimension in their research, as there are strongly rooted subcultures in Pakistani society. These cultural contexts have not only a strong influence on individuals' personalities and traits, but also on their individual consumption habits. Therefore, it appears very likely that incorporating a cultural perspective would lead to more relevant results. Finally, this research could be used for a cross-cultural study of such countries as Pakistan and India and Pakistan and Bangladesh. Such a study could provide a comprehensive understanding of the cultural differences between markets, and thus suggest diverse approaches that professionals and marketers should consider when they operate in global and regional business environments.

Author Contributions: M.Y.B. and X.L. contributed to the conceptualization, formal analysis, investigation, methodology, writing of the original draft, and writing review and editing. All the other authors contributed to the formal analysis, investigation, methodology, and writing review and editing. All authors have read and agreed to the published version of the manuscript.

Funding: This research received no external funding.

Data Availability Statement: The data presented in this study are available on request from the corresponding author. The data are not publicly available due to privacy issues and personal data of respondents such as socio-demographic data has been collected.

Acknowledgments: We would like to thank Syed Asad Hussain for his support provided in the data collection process. We would like to thank the guest editors and three anonymous reviewers for their detailed comments and manuscript reviews.

Conflicts of Interest: The authors declare no conflict of interest.

\section{Appendix A}


Table A1. Measurement items.

\section{Constructs}

Measurement Items

Environmental protection is important to me when making purchases of appliances.

Energy-efficient appliances are important to save natura resources that would be used for producing energy, e.g., coal,

If I can choose between energy efficient and conventiona

appliances, I prefer energy efficient appliances.

Most of the people who are important to me think that I should buy energy-efficient appliances.

Subjective Norms

Using energy-efficient appliances is a social trend.

People whose opinion I respect would buy energy-efficient appliances instead of conventional ones.

I am confident that I would use energy-efficient appliances

even if it is slightly more expensive.

Perceivedbehavioural control

I have the resources, knowledge and ability to use energy-efficient appliances.

I am confident that I would use energy-efficient household

appliances even if another person advises me to use non-energy-efficient appliances.

Energy-efficient appliances respect the environment.

Utilitarian environmental benefits Energy-efficient appliances help to prevent global warming.

Energy-efficient appliances do not pollute the environment.

I like to contribute to the protection of the environment by purchasing energy-efficient appliances.

Warm Glow benefits

I have the feeling of contribution to the well-being of

humanity when buying energy-efficient appliances.

I admire individuals who voluntarily purchase energy-efficient appliances. 
Table A1. Cont.

Constructs

\section{Measurement Items}

1

I feel it is a moral obligation to purchase energy-efficient appliances in fulfilling my responsibility to the environment.

Moral Obligations

I feel it is a moral obligation to purchase energy-efficient appliances although they are expensive.

I feel it is a moral obligation to purchase energy-efficient appliances for environmental protection.

My family thinks I should purchase energy-efficient

appliances in place of conventional appliances.

Normative Belief

My friend thinks I should purchase energy-efficient

appliances in place of conventional appliances.

I value the opinion and feelings of my family \& friends about

my environmentally friendly behavior.

I prefer to check the eco-labels and certifications on

energy-efficient appliances before I purchase

I want to have a deeper insight of the inputs, processes and impacts of appliances before I purchase.

I understand the environmental phrases and symbols on product package.

I prefer to buy products with lower energy grade (low energy consumption).

Purchase Intention refrigerators, washing machines, etc., I prefer energy-saving

$$
\text { models. }
$$

I will buy appliances that consume less electricity.

I will choose energy-efficient appliances when I buy

appliances 


\section{References}

1. Jansson, J.; Marell, A.; Nordlund, A. Green consumer behavior: Determinants of curtailment and eco-innovation adoption. J. Consum. Mark. 2010, 27, 358-370. [CrossRef]

2. Tan, C.-S.; Ooi, H.-Y.; Goh, Y.-N. A moral extension of the theory of planned behavior to predict consumers' purchase intention for energy-efficient household appliances in Malaysia. Energy Policy 2017, 107, 459-471. [CrossRef]

3. Zhou, K.; Yang, S.; Shen, C.; Ding, S.; Sun, C. Energy conservation and emission reduction of China's electric power industry. Renew. Sustain. Energy Rev. 2015, 45, 10-19. [CrossRef]

4. Commission Of The European Communities. Action Plan for Energy Efficiency: Realising the Potential COM (2006) 545 Final; CEC: Brussels, Belgium, 2006.

5. Mills, B.; Schleich, J. Analysis of existing data: Determinants for the adoption of energy-efficient household appliances in Germany. In Sustainable Energy Consumption in Residential Buildings; Springer: Berlin, Germany, 2013; pp. 39-67.

6. Ek, K.; Söderholm, P. The devil is in the details: Household electricity saving behavior and the role of information. Energy Policy 2010, 38, 1578-1587. [CrossRef]

7. Urban, J.; Ščasný, M. Exploring domestic energy-saving: The role of environmental concern and background variables. Energy Policy 2012, 47, 69-80. [CrossRef]

8. Waris, I.; Hameed, I. An empirical study of purchase intention of energy-efficient home appliances: The influence of knowledge of eco-labels and psychographic variables. Int. J. Energy Sect. Manag. 2020, 14, 1297-1314. [CrossRef]

9. Oikonomou, V.; Becchis, F.; Steg, L.; Russolillo, D. Energy saving and energy efficiency concepts for policy making. Energy Policy 2009, 37, 4787-4796. [CrossRef]

10. Mills, B.; Schleich, J. Residential energy-efficient technology adoption, energy conservation, knowledge, and attitudes: An analysis of European countries. Energy Policy 2012, 49, 616-628. [CrossRef]

11. Wang, Z.; Wang, X.; Guo, D. Policy implications of the purchasing intentions towards energy-efficient appliances among China's urban residents: Do subsidies work? Energy Policy 2017, 102, 430-439. [CrossRef]

12. Abrahamse, W.; Steg, L. How do socio-demographic and psychological factors relate to households' direct and indirect energy use and savings? J. Econ. Psychol. 2009, 30,711-720. [CrossRef]

13. Niemeyer, S. Consumer voices: Adoption of residential energy-efficient practices. Int. J. Consum. Stud. 2010, 34, 140-145. [CrossRef]

14. Pothitou, M.; Hanna, R.F.; Chalvatzis, K.J. Environmental knowledge, pro-environmental behaviour and energy savings in households: An empirical study. Appl. Energy 2016, 184, 1217-1229. [CrossRef]

15. Tanner, C.; Wölfing Kast, S. Promoting sustainable consumption: Determinants of green purchases by Swiss consumers. Psychol. Mark. 2003, 20, 883-902. [CrossRef]

16. Jain, S.K.; Kaur, G. Role of socio-demographics in segmenting and profiling green consumers: An exploratory study of consumers in India. J. Int. Consum. Mark. 2006, 18, 107-146. [CrossRef]

17. Jeong, G.; Kim, Y. The effects of energy efficiency and environmental labels on appliance choice in South Korea. Energy Effic. 2015, 8, 559-576. [CrossRef]

18. Lin, J.; Lobo, A.; Leckie, C. The role of benefits and transparency in shaping consumers' green perceived value, self-brand connection and brand loyalty. J. Retail. Consum. Serv. 2017, 35, 133-141. [CrossRef]

19. Zhang, L.; Fan, Y.; Zhang, W.; Zhang, S. Extending the theory of planned behavior to explain the effects of cognitive factors across different kinds of green products. Sustainability 2019, 11, 4222. [CrossRef]

20. International Engergy Agency. Energy Access Outlook 2017: From Poverty to Prosperity; IEA: Paris, France, 2017.

21. Iqbal, S.; Chu, J.; Hali, S.M. Projecting impact of CPEC on Pakistan's electric power crisis. Chin. J. Popul. Resour. Environ. 2019, 17, 310-321. [CrossRef]

22. Rafique, M.M.; Rehman, S. National energy scenario of Pakistan-Current status, future alternatives, and institutional infrastructure: An overview. Renew. Sustain. Energy Rev. 2017, 69, 156-167. [CrossRef]

23. Ali, S.; Danish, M.; Khuwaja, F.M.; Sajjad, M.S.; Zahid, H. The intention to adopt green IT products in Pakistan: Driven by the modified theory of consumption values. Environments 2019, 6, 53. [CrossRef]

24. The World Bank. Energy Efficiency Roadmap for Pakistan; The World Bank: Washington, DC, USA, 2019.

25. Ali, S.; Ullah, H.; Akbar, M.; Akhtar, W.; Zahid, H. Determinants of Consumer Intentions to Purchase Energy-Saving Household Products in Pakistan. Sustainability 2019, 11, 1462. [CrossRef]

26. Aslam, M.; Ahmad, E. Impact of Ageing and Generational Effects on Household Energy Consumption Behavior: Evidence from Pakistan. Energies 2018, 11, 2003. [CrossRef]

27. Koon, O.; Chan, R.Y.; Sharma, P. Moderating effects of socio-cultural values on pro-environmental behaviors. Mark. Intell. Plan. 2020, 38, 603-618. [CrossRef]

28. Park, E.; Kwon, S.J. What motivations drive sustainable energy-saving behavior?: An examination in South Korea. Renew. Sustain. Energy Rev. 2017, 79, 494-502. [CrossRef]

29. Botetzagias, I.; Dima, A.-F.; Malesios, C. Extending the Theory of Planned Behavior in the context of recycling: The role of moral norms and of demographic predictors. Resour. Conserv. Recycl. 2015, 95, 58-67. [CrossRef] 
30. De Medeiros, J.F.; Ribeiro, J.L.D.; Cortimiglia, M.N. Influence of perceived value on purchasing decisions of green products in Brazil. J. Clean. Prod. 2016, 110, 158-169. [CrossRef]

31. Pan, J.Y.; Truong, D. Passengers' intentions to use low-cost carriers: An extended theory of planned behavior model. J. Air Transp. Manag. 2018, 69, 38-48. [CrossRef]

32. Paul, J.; Modi, A.; Patel, J. Predicting green product consumption using theory of planned behavior and reasoned action. J. Retail. Consum. Serv. 2016, 29, 123-134. [CrossRef]

33. Yadav, R.; Pathak, G.S. Young consumers' intention towards buying green products in a developing nation: Extending the theory of planned behavior. J. Clean. Prod. 2016, 135, 732-739. [CrossRef]

34. Khan, H.A.; Pervaiz, S. Technological review on solar PV in Pakistan: Scope, practices and recommendations for optimized system design. Renew. Sustain. Energy Rev. 2013, 23, 147-154. [CrossRef]

35. Acheampong, R.A.; Siiba, A. Modelling the determinants of car-sharing adoption intentions among young adults: The role of attitude, perceived benefits, travel expectations and socio-demographic factors. Transportation 2019, 47, 2557-2580. [CrossRef]

36. Prati, G.; Pietrantoni, L.; Zani, B. The prediction of intention to consume genetically modified food: Test of an integrated psychosocial model. Food Qual. Prefer. 2012, 25, 163-170. [CrossRef]

37. Liao, Y.-K.; Wu, W.-Y.; Pham, T.-T. Examining the Moderating Effects of Green Marketing and Green Psychological Benefits on Customers' Green Attitude, Value and Purchase Intention. Sustainability 2020, 12, 7461. [CrossRef]

38. Hartmann, P.; Apaolaza-Ibáñez, V. Consumer attitude and purchase intention toward green energy brands: The roles of psychological benefits and environmental concern. J. Bus. Res. 2012, 65, 1254-1263. [CrossRef]

39. Allison, T.H.; McKenny, A.F.; Short, J.C. The effect of entrepreneurial rhetoric on microlending investment: An examination of the warm-glow effect. J. Bus. Ventur. 2013, 28, 690-707. [CrossRef]

40. Nunes, P.A.; Schokkaert, E. Identifying the warm glow effect in contingent valuation. J. Environ. Econ. Manag. 2003, 45, 231-245. [CrossRef]

41. Al Mamun, A.; Mohamad, M.R.; Yaacob, M.R.B.; Mohiuddin, M. Intention and behavior towards green consumption among low-income households. J. Environ. Manag. 2018, 227, 73-86. [CrossRef]

42. Maichum, K.; Parichatnon, S.; Peng, K.-C. Application of the extended theory of planned behavior model to investigate purchase intention of green products among Thai consumers. Sustainability 2016, 8, 1077. [CrossRef]

43. Ajzen, I. Constructing a TPB Questionnaire: Conceptual and Methodological Considerations. 2002. Available online: http: / / people.umass.edu/aizen/pdf/tpb.measurement.pdf (accessed on 15 June 2016).

44. Aman, A.L.; Harun, A.; Hussein, Z. The influence of environmental knowledge and concern on green purchase intention the role of attitude as a mediating variable. Br. J. Arts Soc. Sci. 2012, 7, 145-167.

45. Zainudin, N.; Siwar, C.; Choy, E.A.; Chamhuri, N. Evaluating the role of energy efficiency label on consumers' purchasing behaviour. Apcbee Procedia 2014, 10, 326-330. [CrossRef]

46. Nguyen, T.N. Determinants Which Influence Purchase Behaviour of Energy Efficient Household Appliances in Emerging Markets. Goals Sustain. Dev. Responsib. Gov. 2018, 97-110.

47. Mi, L.; Zhu, H.; Yang, J.; Gan, X.; Xu, T.; Qiao, L.; Liu, Q. A new perspective to promote low-carbon consumption: The influence of reference groups. Ecol. Econ. 2019, 161, 100-108. [CrossRef]

48. Wang, Z.; Sun, Q.; Wang, B.; Zhang, B. Purchasing intentions of Chinese consumers on energy-efficient appliances: Is the energy efficiency label effective? J. Clean. Prod. 2019, 238, 117896. [CrossRef]

49. Beck, L.; Ajzen, I. Predicting dishonest actions using the theory of planned behavior. J. Res. Personal. 1991, 25, 285-301. [CrossRef]

50. Verma, V.K.; Chandra, B. An application of theory of planned behavior to predict young Indian consumers' green hotel visit intention. J. Clean. Prod. 2018, 172, 1152-1162. [CrossRef]

51. Li, G.; Li, W.; Jin, Z.; Wang, Z. Influence of Environmental Concern and Knowledge on Households' Willingness to Purchase Energy-Efficient Appliances: A Case Study in Shanxi, China. Sustainability 2019, 11, 1073. [CrossRef]

52. Hua, L.; Wang, S. Antecedents of Consumers' Intention to Purchase Energy-Efficient Appliances: An Empirical Study Based on the Technology Acceptance Model and Theory of Planned Behavior. Sustainability 2019, 11, 2994. [CrossRef]

53. Chen, M.-F. Extending the theory of planned behavior model to explain people's energy savings and carbon reduction behavioral intentions to mitigate climate change in Taiwan-moral obligation matters. J. Clean. Prod. 2016, 112, 1746-1753. [CrossRef]

54. Yuriev, A.; Dahmen, M.; Paillé, P.; Boiral, O.; Guillaumie, L. Pro-environmental behaviors through the lens of the theory of planned behavior: A scoping review. Resour. Conserv. Recycl. 2020, 155, 104660. [CrossRef]

55. Davies, J.; Foxall, G.R.; Pallister, J. Beyond the intention-behaviour mythology: An integrated model of recycling. Mark. Theory 2002, 2, 29-113. [CrossRef]

56. Ertz, M.; Huang, R.; Jo, M.-S.; Karakas, F.; Sarigollu, E. From single-use to multi-use: Study of consumers' behavior toward consumption of reusable containers. J. Environ. Manag. 2017, 193, 334-344. [CrossRef] [PubMed]

57. Wang, P.; Liu, Q.; Qi, Y. Factors influencing sustainable consumption behaviors: A survey of the rural residents in China. J. Clean. Prod. 2014, 63, 152-165. [CrossRef]

58. Rhodes, R.E.; Courneya, K.S. Investigating multiple components of attitude, subjective norm, and perceived control: An examination of the theory of planned behaviour in the exercise domain. Br. J. Soc. Psychol. 2003, 42, 129-146. [CrossRef] [PubMed]

59. Ajzen, I. The theory of planned behavior. Organ. Behav. Hum. Decis. Process. 1991, 50, 179-211. [CrossRef]

60. Ajzen, I. The theory of planned behavior: Frequently asked questions. Hum. Behav. Emerg. Technol. 2020, 2, 314-324. [CrossRef] 
61. Sreen, N.; Purbey, S.; Sadarangani, P. Impact of culture, behavior and gender on green purchase intention. J. Retail. Consum. Serv. 2018, 41, 177-189. [CrossRef]

62. Kaffashi, S.; Shamsudin, M.N. Transforming to a low carbon society; an extended theory of planned behaviour of Malaysian citizens. J. Clean. Prod. 2019, 235, 1255-1264. [CrossRef]

63. Sriram, V.; Forman, A.M. The Relative Importance of Products' Environmental Attributes: A Cross-cultural Comparison. Int. Mark. Rev. 1993, 10. [CrossRef]

64. White, K.; Habib, R.; Hardisty, D.J. How to SHIFT consumer behaviors to be more sustainable: A literature review and guiding framework. J. Mark. 2019, 83, 22-49. [CrossRef]

65. Nadricka, K.; Millet, K.; Verlegh, P.W. When organic products are tasty: Taste inferences from an Organic= Healthy Association. Food Qual. Prefer. 2020, 83, 103896. [CrossRef]

66. Nganje, W.E.; Hughner, R.S.; Patterson, P.M. Perception of risks and preferences for locally grown produce: A marketing system approach. J. Food Prod. Mark. 2014, 20, 196-214. [CrossRef]

67. Fan, L.; Liu, G.; Wang, F.; Geissen, V.; Ritsema, C.J.; Tong, Y. Water use patterns and conservation in households of Wei River Basin, China. Resour. Conserv. Recycl. 2013, 74, 45-53. [CrossRef]

68. Clark, C.F.; Kotchen, M.J.; Moore, M.R. Internal and external influences on pro-environmental behavior: Participation in a green electricity program. J. Environ. Psychol. 2003, 23, 237-246. [CrossRef]

69. Frank-Martin Belz, K.P. Sustainability Marketing: A Global Perspective, 2nd ed.; John Wiley \& Sons, Ltd.: Munich, Germany, 2012.

70. Steinhart, Y.; Ayalon, O.; Puterman, H. The effect of an environmental claim on consumers' perceptions about luxury and utilitarian products. J. Clean. Prod. 2013, 53, 277-286. [CrossRef]

71. Andreoni, J. Giving With Impure Altruism: Applications to Charity and Ricardian Equivalence. J. Polit. Econ. 1989, 97, 1447-1458. [CrossRef]

72. Andreoni, J. Impure Altruism and Donations to Public Goods: A Theory of Warm-Glow Giving. Econ. J. 1990, 100, 464-477. [CrossRef]

73. James Baraz, S.A. The Helper's High. Greater Good Magazine, 1 February 2010.

74. Ritov, I.; Kahneman, D. How people value the environment: Attitudes versus economic values. In Environment, Ethics, and Behavior: The Psychology of Environmental Valuation And Degradation; The New Lexington Press: Francisco, CA, USA, 1997; pp. 33-51.

75. Sánchez-Fernández, R.; Iniesta-Bonillo, M.Á.; Holbrook, M.B. The Conceptualisation and Measurement of Consumer Value in Services. Int. J. Mark. Res. 2009, 51, 1-17. [CrossRef]

76. Wüstenhagen, R.; Bilharz, M. Green Energy Market Development in Germany: Effective Public Policy and Emerging Customer Demand. Energy Policy 2006, 34, 1681-1696. [CrossRef]

77. Gneezy, U.; Rustichini, A. Pay Enough or Don't Pay at All*. Q. J. Econ. 2000, 115, 791-810. [CrossRef]

78. D'Amato, A.; Susanna, M.; Mariangela, Z. Two Shades of (warm) Glow: Multidimensional Intrinsic Motivation, Waste Reduction and Recycling. SEDS Working Paper Series. 2014. Available online: https://ideas.repec.org/p/srt/wpaper/2114.html (accessed on 15 August 2014).

79. Carrington, M.J.; Neville, B.A.; Whitwell, G.J. Why Ethical Consumers Don't Walk Their Talk: Towards a Framework for Understanding the Gap Between the Ethical Purchase Intentions and Actual Buying Behaviour of Ethically Minded Consumers. J. Bus. Ethics. 2010, 97, 139-158. [CrossRef]

80. Ajzen, I. Constructing a Theory of Planned Behavior Questionnaire; University of Massachusetts: Amherst, MA, USA, 2006.

81. Fang, W.-T.; Ng, E.; Wang, C.-M.; Hsu, M.-L. Normative Beliefs, Attitudes, and Social Norms: People Reduce Waste as an Index of Social Relationships When Spending Leisure Time. Sustainability 2017, 9, 1696. [CrossRef]

82. Ajzen, I.; Fishbein, M. Understanding Attitudes and Predicting Social Behavior, 1st ed.; Pearson: London, UK, 1980.

83. Yadav, R.; Pathak, G.S. Determinants of Consumers' Green Purchase Behavior in a Developing Nation: Applying and Extending the Theory of Planned Behavior. Ecol. Econ. 2017, 134, 114-122. [CrossRef]

84. Zuckerman, M.; Reis, H.T. Comparison of three models for predicting altruistic behavior. J. Personal. Soc. Psychol. 1978, $36,498$. [CrossRef]

85. Mamun, A.; Mohiuddin, M.; Ahmad, G.; Ramayah, T.; Fazal, S. Recycling Intention and Behavior among Low-Income Households. Sustainability 2018, 10, 2407. [CrossRef]

86. Chu, P.-Y.; Chiu, J.F. Factors Influencing Household Waste Recycling Behavior: Test of an integrated Model1. J. Appl. Soc. Psychol. 2003, 33, 604-626. [CrossRef]

87. Wu, S.-I.; Chen, J.-Y. A Model of Green Consumption Behavior Constructed by the Theory of Planned Behavior. Int. J. Mark. Stud. 2014, 6, 119. [CrossRef]

88. Stern, P. Toward a Coherent Theory of Environmentally Significant Behavior. J. Soc. Issues 2000, 56, 407-424. [CrossRef]

89. Bamberg, S.; Hunecke, M.; Blöbaum, A. Social Context, Personal Norms and the use of Public Transportation: Two Field Studies. J. Environ. Psychol. 2007, 27, 190-203. [CrossRef]

90. Hwang, J.; Lee, S. Cognitive, affective, normative, and moral triggers of sustainable intentions among convention-goers. J. Environ. Psychol. 2017, 51, 1-13.

91. Onwezen, M.; Antonides, G.; Bartels, J. The Norm Activation Model: An Exploration of the Functions of Anticipated Pride and Guilt in Pro-environmental Behaviour. J. Econ. Psychol. 2013, 39, 141-153. [CrossRef] 
92. Fatoki, O. Factors Influencing the Purchase of Energy-Efficient Appliances by Young Consumers in South Africa. Found. Manag. 2020, 12, 151-166. [CrossRef]

93. Hwang, J. What Motivates Delegates' Conservation Behaviors While Attending a Convention? J. Travel Tour. Mark. 2016, 34, 82-98.

94. Al Mamun, A.; Masud, M.M.; Fazal, S.A.; Muniady, R. Green vehicle adoption behavior among low-income households: Evidence from coastal Malaysia. Environ. Sci. Pollut. Res. 2019, 26, 27305-27318. [CrossRef] [PubMed]

95. Ivancevich, J.M.; Konopaske, R.; Matteson, M.T. Organizational Behavior and Management, 10th ed.; McGraw-Hill Education: New York, NY, USA, 2008.

96. Fishbein, M.; Ajzen, I. Belief, Attitude, Intention and Behaviour: An Introduction to Theory and Research; Philarchive: Boston, MA, USA, 1975; Volume 27.

97. Wang, S.; Fan, J.; Zhao, D.; Yang, S.; Fu, Y. Predicting consumers' intention to adopt hybrid electric vehicles: Using an extended version of the theory of planned behavior model. Transportation 2016, 43, 123-143. [CrossRef]

98. Gadenne, D.; Sharma, B.; Kerr, D.; Smith, T. The influence of consumers' environmental beliefs and attitudes on energy saving behaviours. Energy Policy 2011, 39, 7684-7694. [CrossRef]

99. Egmond, C.; Jonkers, R.; Kok, G. A strategy to encourage housing associations to invest in energy conservation. Energy Policy 2005, 33, 2374-2384. [CrossRef]

100. Lopes, J.R.N.; Kalid, R.D.A.; Rodríguez, J.L.M.; Ávila Filho, S. A new model for assessing industrial worker behavior regarding energy saving considering the theory of planned behavior, norm activation model and human reliability. Resour. Conserv. Recycl. 2019, 145, 268-278. [CrossRef]

101. Wang, B.; Wang, X.; Guo, D.; Zhang, B.; Wang, Z. Analysis of factors influencing residents' habitual energy-saving behaviour based on NAM and TPB models: Egoism or altruism? Energy Policy 2018, 116, 68-77. [CrossRef]

102. Sultan, P.; Tarafder, T.; Pearson, D.; Henryks, J. Intention-behaviour gap and perceived behavioural control-behaviour gap in theory of planned behaviour: Moderating roles of communication, satisfaction and trust in organic food consumption. Food Qual. Prefer. 2020, 81, 103838. [CrossRef]

103. Finlay, K.A.; Trafimow, D.; Moroi, E. The Importance of Subjective Norms on Intentions to Perform Health Behaviors. J. Appl. Soc. Psychol. 1999, 29, 2381-2393. [CrossRef]

104. Black, J.; Stern, P.; Elworth, J. Personal and Contextual Influences on Household Energy Adaptations. J. Appl. Psychol. 1985, 70, 3-21. [CrossRef]

105. Ha, H.-Y.; Janda, S. Predicting Consumer Intentions to Purchase Energy-Efficient Products. In The Customer is NOT Always Right? Marketing Orientationsin a Dynamic Business World; Campbell, C.L., Ed.; Springer International Publishing: Cham, Switzerland, 2017; p. 897.

106. Zhao, H.; Gao, Q.; Wu, Y.; Wang, Y.; Zhu, X. What affects green consumer behavior in China? A case study from Qingdao. J. Clean. Prod. 2014, 63, 143-151. [CrossRef]

107. Chen, M.-F.; Tung, P.-J. Developing an extended Theory of Planned Behavior model to predict consumers' intention to visit green hotels. Int. J. Hosp. Manag. 2014, 36, 221-230. [CrossRef]

108. Bamberg, S. How does environmental concern influence specific environmentally related behaviors? A new answer to an old question. J. Environ. Psychol. 2003, 23, 21-32. [CrossRef]

109. Devi, J.; Pudaruth, S.; Noyaux, M. Analysing the impact of green marketing strategies on consumer purchasing patterns in Mauritius. World J. Entrep. Manag. Sustain. Dev. 2012, 8, 36-59.

110. Laroche, M.; Toffoli, R.; Kim, C.; Muller, T.E. The influence of culture on pro-environmental knowledge, attitudes, and behavior: A Canadian perspective. Adv. Consum. Res. 1996, 23, 196-202.

111. Minton, E.; Spielmann, N.; Kahle, L.; Kim, C.H. The subjective norms of sustainable consumption: A cross-cultural exploration. J. Bus. Res. 2017, 82, 400-408. [CrossRef]

112. Ramayah, T.; Lee, J.; Mohamad, O. Green product purchase intention: Some insights from a developing country. Resour. Conserv. Recycl. 2010, 54, 1419-1427. [CrossRef]

113. Nguyen, T.; Yang, Z.; Nguyen, T.N.; Johnson, L.; Cao, T. Greenwash and Green Purchase Intention: The Mediating Role of Green Skepticism. Sustainability 2019, 11, 2653. [CrossRef]

114. Lee, S. Consumers' Value, Environmental Consciousness, and Willingness to Pay more toward Green-Apparel Products. J. Glob. Fash. Mark. 2011, 2, 161-169. [CrossRef]

115. Chen, F.; Chen, H.; Guo, D.; Long, R. Analysis of undesired environmental behavior among Chinese undergraduates. J. Clean. Prod. 2017, 162, 1239-1251. [CrossRef]

116. Ha, H.Y.; Janda, S. Predicting consumer intentions to purchase energy-efficient products. J. Consum. Mark. 2012, 29, 461-469. [CrossRef]

117. Nguyen, T.N.; Lobo, A.; Nguyen, B.K. Young consumers' green purchase behaviour in an emerging market. J. Strateg. Mark. 2018, 26, 583-600. [CrossRef]

118. Alam, S.S.; Hashim, N.H.N.; Rashid, M.; Omar, N.A.; Ahsan, N.; Ismail, M.D. Small-scale households renewable energy usage intention: Theoretical development and empirical settings. Renew. Energy 2014, 68, 255-263. [CrossRef]

119. Calvo-Porral, C.; Faíña-Medín, A.; Nieto-Mengotti, M. Satisfaction and switching intention in mobile services: Comparing lock-in and free contracts in the Spanish market. Telemat. Inform. 2017, 34, 717-729. [CrossRef] 
120. Wang, B.; Li, J.; Sun, A.; Wang, Y.; Wu, D. Residents' Green Purchasing Intentions in a Developing-Country Context: Integrating PLS-SEM and MGA Methods. Sustainability 2019, 12, 30. [CrossRef]

121. Fornell, C.; Larcker, D.F. Evaluating Structural Equation Models with Unobservable Variables and Measurement Error. J. Mark. Res. 1981, 18, 39-50. [CrossRef]

122. Henseler, J.; Ringle, C.M.; Sarstedt, M. A new criterion for assessing discriminant validity in variance-based structural equation modeling. J. Acad. Mark. Sci. 2015, 43, 115-135. [CrossRef]

123. Sarstedt, M.; Ringle, C.M.; Henseler, J.; Hair, J.F. On the Emancipation of PLS-SEM: A Commentary on Rigdon (2012). Long Range Plan. 2013, 47, 154-160. [CrossRef]

124. Henseler, J. Why generalized structured component analysis is not universally preferable to structural equation modeling. J. Acad. Mark. Sci. 2012, 40, 402-413. [CrossRef]

125. Ek, K. Public and private attitudes towards "green" electricity: The case of Swedish wind power. Energy Policy 2005, 33, 1677-1689. [CrossRef]

126. Ajzen, I.; Driver, B.L. Prediction of Leisure Participation from Behavioral, Normative, and Control Beliefs: An Application of the Theory of Planned Behavior. Leis. Sci. 1991, 13, 185-204. [CrossRef]

127. Wang, Z.; Zhang, B.; Li, G. Determinants of energy-saving behavioral intention among residents in Beijing: Extending the theory of planned behavior. J. Renew. Sustain. Energy 2014, 6, 053127. [CrossRef]

128. Jayanti, R.; Gowda, R. Sustainability dilemmas in emerging economies. IIMB Manag. Rev. 2014, 26, 130-142. [CrossRef]

129. Kirmani, M.D.; Khan, M.N. Environmental concern to attitude towards green products: Evidences from India. Serb. J. Manag. 2016, 11, 159-179.

130. Soomro, Y.A. Antecedents of brand loyalty in the fashion industry of Pakistan: Moderating effect of Individual-level collectivist values. MPRA 2019, 6, 33-46.

131. Higueras-Castillo, E.; Liébana-Cabanillas, F.; Muñoz-Leiva, F.; Molinillo, S. The role of collectivism in modeling the adoption of renewable energies: A cross-cultural approach. Int. J. Environ. Sci. Technol. 2019, 16, 2143-2160. [CrossRef]

132. Mohai, P. Men, women, and the environment: An examination of the gender gap in environmental concern and activism. Soc. Nat. Resour. 1992, 5, 1-19. [CrossRef]

133. Diamantopoulos, A.; Schlegelmilch, B.B.; Sinkovics, R.R.; Bohlen, G.M. Can socio-demographics still play a role in profiling green consumers? A review of the evidence and an empirical investigation. J. Bus. Res. 2003, 56, 465-480. [CrossRef]

134. Singh, V.; Chauhan, S.C.; Tejyan, S. Greenhouse gas emission reduction potentials in air transport: A structural equation modelling-based multi-group analysis. Technol. Anal. Strateg. Manag. 2017, 29, 442-461. [CrossRef] 